JABES

28,3

204

Received 28 April 2021

Revised 15 May 2021

18 May 2021

Accepted 18 May 2021

\section{The effect of transformational leadership on nonfamily international intrapreneurship behavior in family firms: the mediating role of psychological empowerment}

\author{
Giang Thi Thuy Huynh
}

Faculty of International Economic Relations, University of Economics and Law, Ho Chi Minh City, Vietnam and Vietnam National University, Ho Chi Minh City, Vietnam

\begin{abstract}
Purpose - The study aims to reveal the effects of transformational leadership on nonfamily employee international intrapreneurship with the mediating role of psychological empowerment.

Design/methodology/approach - The study sample consists of 379 employees at 132 family export and import firms in Ho Chi Minh City of Vietnam. The data is analyzed by a partial least squares structural equation modeling (PLS-SEM).

Findings - The paper reveals that transformational leadership had a positive and significant influence on nonfamily employee international intrapreneurship. The effect of transformational leadership on international intrapreneurship is strongly mediated by psychological empowerment.

Practical implications - Family firms would have to form the architecture and mechanisms for supporting the dedication of nonfamily international intrapreneurship actions with transformational leadership and psychological empowerment.

Originality/value - The paper grants the driving mechanism of the transformational leadership on nonfamily employee international intrapreneurship through the mediating role of employee psychological empowerment in the context of family businesses in an emerging market.
\end{abstract}

Keywords International intrapreneurship, Psychological empowerment, Strategic renewal behavior, Transformational leadership, New business venture behavior

Paper type Research paper

\section{Introduction}

Family-owned companies blend and steady conflicting forces, facing pressures between the aspire to protect the core values of family, control power and tradition by staying grounded in the local market and the demand to explore and exploit the benefits of global market expansion (Arregle et al., 2017; Bird and Wennberg, 2014; Gómez-Mejía et al., 2010). Firms endure when they possess a corporate culture that balances the continuity of core concepts and necessary change (Collins and Porras, 1994). In the era of hyper-competition and dynamism, the international business of family firms is now more dependent on the pursuit of new business

\section{JEL Classification — D23, L22, M12}

(C) Giang Thi Thuy Huynh. Published in Journal of Asian Business and Economic Studies. Published by Emerald Publishing Limited. This article is published under the Creative Commons Attribution (CC BY 4.0) licence. Anyone may reproduce, distribute, translate and create derivative works of this article (for both commercial and non-commercial purposes), subject to full attribution to the original publication and authors. The full terms of this licence may be seen at http://creativecommons.org/licences/by/4.0/ legalcode
Journal of Asian Business and Economic Studies
Vol. 28 No. 3, 2021 pp. $204-224$

Emerald Publishing Limited 2515-964X

DOI 10.1108/JABES-04-2021-0047 
ventures, the ability to innovate, continuous self-renewal and adoption of a proactive stance (Ratten, 2020). Going beyond domestic borders to explore opportunities and exploit nonlocation bound firm-specific advantages at the global level has thus become imperative to stay ahead of competitors (Alayo et al.,2019). Transnational resources of entrepreneurs and employees foster a firm's competitiveness (Mostafiz et al., 2020). Prior research suggests that international intrapreneurship might reinvigorate firms performance with innovation and change adaption in the domestic and external environments (Mubarik et al., 2020; Skarmeas et al., 2016). However, intrapreneurship studies in the international business context of the family firm in emerging markets have dropped behind those in Western settings (De Clercq and Zhou, 2014; Samiee et al., 2015; Urbano et al., 2013). Precompetitive researches concentrated largely on corporate entrepreneurship within large size established firms operating in the manufacturing sector, with macro-level analysis (Hill and Birkinshaw, 2014). The amount of insignificant quantity of scholarly work devoted to the topics of corporate entrepreneurial activities in family-owned firms and disregarding the micro-foundations and the role of nonfamily members (Glinyanova et al., 2021). This exclusive phenomenon demands a specific and contextualized reassessment of established theories that integrate international corporate entrepreneurship in the context of family-owned firms and international business, which might help understand the differences of family-owned firms in approaching international corporate entrepreneurship. The conceptual research model is presented as Figure 1.

Leadership is a vital factor in the orientation of follower's positive attitude and innovation behavior (Lord et al., 2020; Rao-Nicholson et al., 2016; Usman et al., 2021). Transformational leadership is one of the most relevant leadership models in family-owned companies (Arnold, 2017; Fries et al., 2020; Vallejo, 2011). Family-owned firms face a conflict of interest between maintaining core family values and changing in response to market needs and stakeholders. The leader or head of the family experiences a state of emotional conflict that causes leadership to be exercised in family companies in a transformative type (Tipu, 2018). Transformational leadership is a significant contributor to organizational change due to leader able to motivate and support employee commitment to the change, form a shared perspective among managers and followers, and concerning high inherent value to goal achievement, with effective human resource management implementation (Farahnak et al., 2020; Galbreath et al., 2020; Wang et al., 2014).

Organizations need to exploit the entrepreneurial potential at multiple organizational levels, each individual within the organization should be given the empowerment to access information, resources and support to perform corporate entrepreneurship (Kanter, 1985). Employee empowerment is an advanced method for enhancing efficiency through the development of commitment among positive behaviors (AlKahtani et al., 2021; Francis and Alagas, 2020). Empowerment helps employees to act proactively based on their perception of ownership in decision-making instead of due to the impact of power mechanisms or decentralization in the organization (Malik et al., 2021). There is a significant demand aim to explore the influence of institutional characteristics and national cultures of different settings on the form and success of corporate entrepreneurship (Lampe et al., 2020). Although transformational leadership is recognized to be a vital factor of organizational performance, very few trials have investigated the influencing mechanism of transformational leadership on nonfamily employee international intrapreneurship and through a mediating role of psychological empowerment.

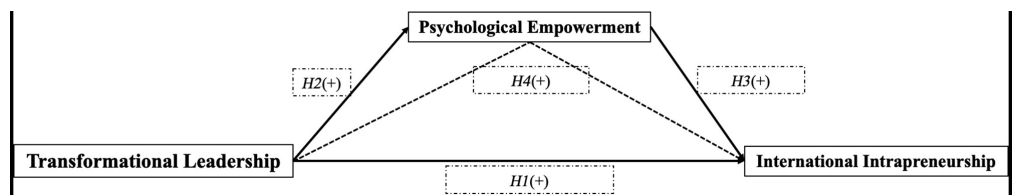

The effect of transformational leadership
Figure 1. Conceptual framework 
JABES 28,3

\section{6}

The paper aims to delve into the direct and indirect effects of transformational leadership on nonfamily employee international intrapreneurship. The paper grants the direct influencing mechanism of transformational leadership on nonfamily employee international intrapreneurship and mediating role of family factors for employee psychological empowerment.

\section{Review of literature and hypothesis development \\ 2.1 Theoretical foundations}

Internationalization encompasses many processes, including the internationalization of markets, production, labor and capital (Bai et al., 2021). Internationalization can be described as innovative, proactive and risk-taking business behaviors (Covin and Slevin, 1991; McDougall and Oviatt, 2000). The process and internationalization performance of firms may be explained by prestigious internationalization models or theories built with different underlying assumptions and structures, namely the Uppsala model (Johanson and Vahlne, 1990), network model (Johanson and Vahlne, 1990), the resource-based view (Hart, 1995), elective theory (Dunning, 1980) and international entrepreneurship theory (McDougall and Oviatt, 2000). Uppsala model emphasizes the active role of entrepreneurs in assuming that firms are not averse to risk to internationalize and the necessary knowledge to enter new markets progress is possibly offered by a firm experience concerning overseas activities (Johanson and Vahlne, 1990). Firm competitiveness, especially the knowledge-intensive business, is linked to its talent base and embeddedness in international networks providing business opportunities (Wan et al., 2020). Based on the resource-based view perspective, firm internationalization is dependent on valuable, hard-to-imitate and irreplaceable resources that contribute to a company's core or unique competencies and lead to long-term competitive advantage (Hart, 1995). Company resources include all tangible and intangible assets, allowing the company to create and apply value-enhancing strategies (Wernerfelt, 1995). In particular, human capital is crucial for economic growth and business opportunities. In international relationships, human capital includes knowledge, skills, talents and experience that are used to provide value to a company (Javalgi and Todd, 2011). Dunning (1980) introduces an eclectic model to explain foreign investment activities according to specific advantages of ownership, location-specific advantage and intrinsic advantage. Ownership advantage is companyspecific resources or capabilities (such as international experience, human capital), while location-specific advantages (such as market potential from highly open economies) refer to the existing manufacturing and institutional factors in a particular country/market. The advantage of internalization depends on the ability of the foreign company to manage and coordinate internal activities (Dunning, 1980). International entrepreneurship theory emphasizes the role of innovation, proactive and risk-taking behavior among key actors facilitate early and accelerated international expansion (McDougall and Oviatt, 2000). SMEs have their own and unique internationalization approach, and there are no common models for all types of firms (Dabic et al., 2020). The study applied the resource-based theory for the study of intrapreneurship, focusing on the role of human capital with international intrapreneurship for firm performance. International business enterprises in emerging economies have limited international business life and resources, which need to follow international business theory steps, which emphasize the linear, ordered and sequential nature of the internationalization process (Schwens et al., 2018). Corporate entrepreneurship theory might help provide a more robust explanation for firm performance, which emphasizes the dynamic, often chaotic, aspects of early internationalization where skills, experience and social networks play a dominant role (Ahimbisibwe et al., 2020). Moreover, previous international business studies are viewed as paying insufficient attention to individual importance with their human capital for SMEs internationalization (Mubarik et al., 2020; Oviatt and McDougall, 1994). 


\subsection{Transformational leadership and international intrapreneurship}

Transformational leadership has been acknowledged as an underlying determinant of organizational change, measured by four dimensions, namely idealized influence, inspirational motivation, intellectual stimulation and individualized consideration (Avolio and Bass, 2004; Shao et al., 2017; Watts et al., 2020; Yang et al., 2019).

Intrapreneurship adverts entrepreneurial activities in existing organizations (Antoncic and Hisrich, 2003). International intrapreneurship is employed as a phenomenon in firms that undergo internationalization (Hisrich, 2013). International intrapreneurship might be used as a mechanism in the international strategy and is intended to create value in organizations (Oviatt and McDougall, 2005). The differentiation in economic, political, cultural and technological environments are crucial factors that make international intrapreneurship more complex in relation to domestic settings (Onetti et al, 2012). Two features of intrapreneurship, including employee strategic renewal behavior and new business venture behavior, play a crucial role in building theory in the context of international business (Do and Luu, 2020). International joint venture behavior includes activities aimed at linking, enhancing, or attracting capital for new business projects in international markets. International strategic renewal behavior is actions that take advantage of core competencies and seize market opportunities to comprehensively innovate strategies from products and services to operational processes, organizational strategies to improve the organization's competitiveness in the international market (Luu, 2020; Woo, 2018). The behavioral and bottom-up approaches are seemly to be appropriate in explaining the intrapreneurship concept as intrapreneurship is more about self-motivated, proactive and action-oriented employees.

Transformational leadership dimensions are positively related to innovative behavior (Afsar and Umrani, 2019; Amankwaa et al, 2019; Huynh, 2021; Sanders and Shipton, 2012; Shafi et al, 2020; Tung, 2016). Transformational leaders might promote employee creativity process engagement with the creative-self-efficacy, horizontal participation, resource availability and supportive climate (Boukamcha, 2019; Mahmood et al., 2019; Moriano et al, 2014; Rigtering and Weitzel, 2013; Yariv and Galit, 2017). Transformational leadership can motivate individuals to change and improve subordinates to think creatively, problem analysis from multiple angles and look at new solutions when solving corporate problems (Khalili, 2016). Transformational leadership guides employees, giving them confidence and motivation to adapt to change, bringing added value for innovation performance (Lei et al., 2020).

Although leadership is proven to be a significant premise of intrapreneurship, its effects depend on the organizational cultural context, and in many cases, can hinder corporate innovation (Montreuil et al, 2020). Familiness is a resource for strategic entrepreneurship in family-owned firms (Arzubiaga et al.,2018; Kansikas et al.,2012). The presence of a family CEO and the percentage of family directors are found to significantly influence innovativeness (Deman et al. 2018). Transformational leadership is particularly relevant in family companies, where great power and responsibility are delegated to the leadership (Arnold, 2017). The power of a transformative leader in family-owned firms and transformational leadership are crucial for creating organizational institutions, strategic directions, which can motivate a company to seek and implement innovative ideas to promote, create and enhance its competitive edge through strategic renewal and business venture (Anning-Dorson and Nyamekye, 2020). Family member CEO risk-taking propensity has a positive effect on new product portfolio innovativeness in family-owned firms (Kraiczy et al, 2015). Besides, transformational leadership is recognized to be a vital factor of organizational change and innovation performance; very few trials have investigated the influencing mechanism of transformational leadership constructs on employee intrapreneurial behavior in the context of family-owned firms.

H1. Transformational leadership directly and positively influences nonfamily employee international intrapreneurship in family-owned firms.
The effect of transformational leadership 
JABES 28,3

\subsection{Transformational leadership and employee psychological empowerment}

Components of psychological empowerment consist of constructs self-determination, competence, meaning and impact (Spreitzer, 1995). Transformational leadership can influence employee empowerment by providing accurate and relevant information about vision, mission and strategic goals in a clear and transparent communication environment where real responsibility is communicated publicly (Avolio and Bass, 2004; Jha, 2014; Pradhan et al., 2017). Empowerment is content or product of individualized consideration in transformational leadership, but it is also related to intellectual stimulation. Transformational leadership focuses on developing followers through effective empowerment, empowering leaders through role models, allowing employee participation in fitting functions that can promote creative behavior within the organization (Naqshbandi and Tabche, 2018). Transformational leaders are positively linked with work and psychological empowerment (Lan and Chong, 2015).

Transformational leaders in family-owned companies can develop employee ownership through ownership power and transformational leadership, which might elevate employee emotions and engage employees in the common goals as the leader and organization (Memili et al., 2013). Transformational leaders can transform their employees to actively develop an entrepreneurial mindset and foster innovation processes throughout the family-owned firm (De Massis et al., 2016). Nonfamily employee's feeling of sense, ownership and belonging to the organization is an important source of their satisfaction under the impact of transformational leadership (Sorenson, 2000). The combination of ownership power, strategic direction and characteristics of transformational leadership make family-owned leaders more successful in adopting a transformational leadership style (Bauweraerts et al., 2021; Pearson and Marler, 2010). However, recent findings suggest that this is not always such a simple relationship (Arnold, 2017). In this study, we investigate the relationship between transformational leadership and nonfamily employee psychological empowerment in family-owned firms.

H2. Transformational leadership directly and positively influences nonfamily employee psychological empowerment in family-owned firms.

\subsection{Employee psychological empowerment and international intrapreneurial behavior}

Psychological empowerment for employees means that the organization provides resources for employees in performing positive organizational behaviors via relationship building (Farahani and Falahati, 2007; Hashemi and Nadi, 2012; Mahmoud et al., 2019; Park et al., 2014; Sengar et al., 2020). Organizational empowerment is a mechanism that not only influences the employee attitude toward the organization through creating/enhancing loyalty, value congruence and affective commitment but also leads to self-empowerment (Malik et al., 2021; Moghaddas et al., 2020).

Organization empowered climates with good communication, high levels of participation and trust, decentralized decision-making and a friendly atmosphere, which relate to firm innovativeness (Anning-Dorson and Nyamekye, 2020). Empowerment helps employees proactively act based on their perception of ownership in decision-making rather than the impact of power or decentralized mechanisms in the organization. However, a pleasant work environment with a high degree of empowerment can produce negative consequences with uncontrolled intrapreneurship behavior (Hashimoto and Nassif, 2014). Conversely, an autocratic leader who maintains a high concentration of power, or attempts to maintain family ownership in the organization, will also discourage creativity and innovation (Craig and Moores, 2006; Pittino and Visintin, 2009). Therefore, a balanced approach is needed to maintain organizational stability while encouraging intrapreneurship behavior. The role of employee psychological empowerment on intrapreneurship through is a deficiency in previous studies in family-owned firms. 
H3. Psychological empowerment directly and positively influence nonfamily employee international intrapreneurship in family-owned firms.

\subsection{The mediating role of psychological empowerment on the relationships between transformational leadership and international intrapreneurial behavior}

Although several investigations have granted the positive associations between leadership role and outcomes at organizational and individual levels, the controlled mechanisms underlying this link is vague (Luu and Phan, 2020). Previous studies have revealed the crucial role of psychological empowerment in explaining the relationship between leadership styles and employees outcomes through mediating effect (Begum et al., 2020; Fong and Snape, 2015), moderating effect (Özarall, 2015) and as a direct determinant (Bester et al., 2015). Besides, recent findings emphasized the mediating effects of psychological empowerment in relationships between transformational leadership and organizational behaviors of employees and organizational success (Ali et al., 2020; Bose et al., 2020; Lei et al., 2020; Mansoor and Ali, 2020; Stanescu et al., 2020). Highly transformative leadership behavior increases employee ownership, laying the foundation for cohesion and a higher, more sustainable level of innovation capacity in family-owned firms (Rau et al., 2019; Stanescu et al., 2020). Contrary to these results, the correlations of leadership styles and innovative behavior are not mediated by empowerment in a few studies (Farrukh et al., 2019). Unfortunately, the influencing mechanism of transformational leadership on intrapreneurship through the mediating role of employee psychological empowerment is fuzzy in previous studies in the field of family-owned firms.

H4. Employee psychological empowerment partially mediates the positive relationship between transformational leadership and employee international intrapreneurship predicted by Hypothesis 1 .

\section{Methodology}

\subsection{The sample and data collection}

Intrapreneurship is significant for international family firms, and based on their distribution channels, are mostly dependent on direct marketing strategy through knowledge, skills and innovation among employees (Klofsten et al.,2021; Mubarik et al.,2020). Vietnam is an emerging market experiencing a high rate of economic growth in addition to societal concerns, determined by expanded trade and investment activities, the different political, economic, social and labor contexts. Moreover, Vietnam is one of the countries with substantial economic openness, is an active agent in international integration, and a member of the 15 FTAs by 2021, which might boost international business development. Therefore, Vietnam might also become a suitable environment for the development and testing of modern business and theoretical management models in the context of emerging and transforming economies.

Scholars principally take for granted the "rules of thumb" for determining sample size for SEM due to the lack of a single universally accepted method. In this paper, the sample size is determined by the "rules of thumb" and necessary parameter values, including anticipated effect size, desired statistical power level, number of latent variables, number of observed variables and probability level (Soper, 2020). The study adopts a sample of 379 key role employees at 132 Vietnamese family import and export firms in the Ho Chi Minh City of Vietnam, based on a nonprobability sampling method with a convenience sample technique. The survey is conducted during July 2020-December 2020. The correspondent list is supplied by the human resource and administration department managers who approve participating in the research. Employees are voluntary and are informed that their responses would remain anonymous and confidential. The collection of data is completed using a direct interviewing method by the authors, which is considered apposite for Vietnamese culture, where communication is primarily through interpersonal interaction. Furthermore, in emerging
The effect of transformational leadership 
JABES 28,3

\section{0}

economies as Vietnam, an on-the-job interview method is needed to control the quality and reliability of data (Do and Luu, 2020). The response rate in this study is $90.39 \%$ (of 420 questionnaires distributed), which is adequate for organizational research (Baruch and Holtom, 2008). Table 1 reveals the sample representativeness with necessary parameter values.

\subsection{Measures}

The present study adopted the self-reported reflective scale for all constructs in the model, which are measured the employee perceptions. Transformational leadership dimensions:

\begin{tabular}{|c|c|c|}
\hline Demographic characteristics & Frequency & Percentage \\
\hline \multicolumn{3}{|l|}{ Gender } \\
\hline 1. Male & 215 & 56.7 \\
\hline 2. Female & 164 & 43.3 \\
\hline \multicolumn{3}{|l|}{ Age } \\
\hline 1. Less than 25 years & 93 & 24.5 \\
\hline 2. $25-34$ years & 164 & 43.3 \\
\hline 3. $34-44$ years & 75 & 19.8 \\
\hline 4. $>45$ years & 47 & 12.4 \\
\hline \multicolumn{3}{|l|}{ Education level } \\
\hline 1. With a bachelor level or upper & 263 & 69.4 \\
\hline 2. Other & 116 & 30.6 \\
\hline \multicolumn{3}{|l|}{ Number of years in an organization } \\
\hline 1. $<3$ years & 99 & 26.1 \\
\hline 2. $3-5$ years & 160 & 42.2 \\
\hline 3. $6-10$ years & 72 & 19.0 \\
\hline 4. More than ten years & 48 & 12.7 \\
\hline \multicolumn{3}{|l|}{ Average income/ month } \\
\hline 1. Under US\$ 500 & 67 & 17.7 \\
\hline 2. US $\$ 500-750$ & 186 & 49.0 \\
\hline 3. US $\$ 750-1,000$ & 73 & 19.3 \\
\hline 4. Over 1,000 USD & 53 & 14.0 \\
\hline \multicolumn{3}{|l|}{ Management level } \\
\hline 1. Middle-level manager & 133 & 35.1 \\
\hline 2. Operational employee & 246 & 64.9 \\
\hline \multicolumn{3}{|l|}{ Firm types } \\
\hline 1. Manufacturing firms & 63 & 47.7 \\
\hline 2. Service firms & 69 & 52.3 \\
\hline \multicolumn{3}{|l|}{ Firm age at internationalization } \\
\hline 1. Under three years & 27 & 20.5 \\
\hline 2. More than three years & 105 & 79.5 \\
\hline \multicolumn{3}{|l|}{ Sample size calculator for PLS-SEM } \\
\hline 1. Anticipated effect size & 0.30 & \\
\hline 2. Desired statistical power level & 0.95 & \\
\hline 3. Number of latent variables & 10 & \\
\hline 4. Number of observed variables & 35 & \\
\hline 5. Probability level & 0.05 & \\
\hline 6. Minimum sample size to detect the effect & 270 & \\
\hline 7. Minimum sample size for model structure & 138 & \\
\hline 8. Recommended minimum sample size & 270 & \\
\hline Actual sample size in the study & 379 & \\
\hline
\end{tabular}

Table 1. 
Four subdimensions measure the transformational leadership from the multifactor leadership questionnaires, including idealized influence (4-items, e.g. "Our manager views the ethical impacts of his/ her decisions."; Cronbach's Alpha $=0.93$ ), inspirational motivation (3-items, e.g. "Our manager provides appealing images about what we can do."; Cronbach's Alpha $=0.89$ ), intellectual stimulation (mean of 4-items, e.g. "Our manager has stimulated me to look at things in new ways."; Cronbach's Alpha $=0.88$ ), and individualized consideration (3-items, e.g. "Our manager considers me as having different needs, abilities, and aspirations from others."; Cronbach's Alpha = 0.89) (Avolio and Bass, 2004; Bass and Avolio, 1997). Employees give the perception of their direct manager's department leadership behavior, which is given on a five-point Likert scale ranging from $1=$ never to $5=$ always.

3.2.1 Intrapreneurial behaviors. Measurement scale by Do and Luu (2020) is adopted, which includes two dimensions, employee strategic renewal behavior, adapting 3-items (e.g. "I attempt actions to transform the existing product/service for our firm."; Cronbach's Alpha $=0.87$ ), and employee new business venturing behavior, adapting 6-items (e.g. "I attempt to establish agencies externally for our firm."; Cronbach's Alpha $=0.88$ ). Employees give the self-assessment on their intrapreneurial behaviors, which is given on a five-point Likert scale ranging from $1=$ never to $5=$ always.

3.2.2 Psychological empowerment. Spreitzer's (1995) psychological empowerment questionnaire is adopted, including four constructs meaning (mean of 3-items, e.g. "The work I do is meaningful to me."; Cronbach's Alpha $=0.89$ ), competence (mean of 3-items, e.g. "I am confident about my ability to do my job."; Cronbach's Alpha = 0.90), self-determination (mean of 3-items, e.g. "I have significant autonomy in determining how I do my job."; Cronbach's Alpha = 0.89), and impact (mean of 3-items, e.g. "My impact on what happens in my department is large.”; Cronbach's Alpha $=0.88$ ). Employees give the self-assessment of their psychological empowerment, which is given on a five-point Likert scale ranging from $1=$ disagree completely to $5=$ agree.

\subsection{Common method bias testing}

Both the procedural and the statistical methods suggested by Podsakoff et al. (2003) are used in this study to address the common method bias. First, a brief explanation in the introduction is included in the questionnaires without implying any relationship between the exogenous and endogenous variables. Second, to overcome any issues of bias, the questionnaire is pretested, the confidentiality of the respondents is reiterated, and it is ensured there is no "right or wrong" answer. Third, Harman's single factor test is used to check the existence of common method bias. The results indicated that the single factor could explain only $33.68 \%$ of the variance; thus, there is no common method bias presented in the data.

\section{Results}

Evaluation of partial least squares-structural equation modeling results includes two steps examining the measurement models and assessing the structural model with the specific procedure and relevant assessment criteria by Hair et al. (2019).

\subsection{Examining the measurement models}

Examining the indicator loadings. PLS-SEM Algorithm technique is chosen for analyzing the data and proposed hypotheses using SmartPLS 3 software (Ringle et al., 2015). The estimation results indicate the indicator loadings of the constructs in the model above 0.64 or higher, which reveal that the construct explains more than $50 \%$ of the indicator variance, thus providing acceptable item reliability (Hair et al., 2019).

Assessing internal consistency reliability. Table 2 shows that composite factor reliability coefficients of the constructs (C.R) are ranged from 0.83 to 0.90 , which met the standard good reliability of internal consistency (Jöreskog, 1971).

The effect of transformational leadership 


\begin{tabular}{|c|c|c|c|c|c|c|}
\hline $\begin{array}{l}\text { JABES } \\
283\end{array}$ & Variables & Items & Mean & S.D. & C.R. & AVE \\
\hline \multirow[b]{2}{*}{212} & $\begin{array}{l}\text { Transformational leadership } \\
\text { 1. Idealized influence } \\
\text { 2. Inspirational motivation } \\
\text { 3. Intellectual stimulation } \\
\text { 4. Individualized consideration }\end{array}$ & $\begin{array}{l}4 \\
3 \\
4 \\
3\end{array}$ & $\begin{array}{l}3.87 \\
3.94 \\
3.74 \\
3.93\end{array}$ & $\begin{array}{l}0.61 \\
0.59 \\
0.55 \\
0.56\end{array}$ & $\begin{array}{l}0.86 \\
0.84 \\
0.86 \\
0.88\end{array}$ & $\begin{array}{l}0.61 \\
0.58 \\
0.68 \\
0.70\end{array}$ \\
\hline & \multirow{2}{*}{$\begin{array}{l}\text { Employee psychological empowerment } \\
\text { 5. Meaning } \\
\text { 6. Competence } \\
\text { 7. Self-determination } \\
\text { 8. Impact }\end{array}$} & & & & & \\
\hline & & $\begin{array}{l}3 \\
3 \\
3 \\
3\end{array}$ & $\begin{array}{l}3.93 \\
3.96 \\
3.95 \\
3.93\end{array}$ & $\begin{array}{l}0.59 \\
0.60 \\
0.59 \\
0.57\end{array}$ & $\begin{array}{l}0.88 \\
0.85 \\
0.88 \\
0.83\end{array}$ & $\begin{array}{l}0.59 \\
0.62 \\
0.67 \\
0.65\end{array}$ \\
\hline $\begin{array}{l}\text { Table } 2 \text {. } \\
\text { Results of reliability } \\
\text { and convergent } \\
\text { validity tests }\end{array}$ & $\begin{array}{l}\text { International intrapreneurship } \\
\text { 9. Employee international strategic renewal behavior } \\
\text { 10. Employee international new business venture behavior }\end{array}$ & $\begin{array}{l}3 \\
6\end{array}$ & $\begin{array}{l}3.89 \\
3.78\end{array}$ & $\begin{array}{l}0.66 \\
0.58\end{array}$ & $\begin{array}{l}0.85 \\
0.90\end{array}$ & $\begin{array}{l}0.65 \\
0.60\end{array}$ \\
\hline
\end{tabular}

Addressing the convergent validity. The average variance extracted (AVE) for each construct in the model above the recommended threshold of 0.58 or higher indicates the convergent validity of each construct measure (Hair et al., 2019) (see Table 2).

Assessing discriminant validity. Henseler et al. (2015) introduce a novel approach for assessing discriminant validity, the heterotrait-monotrait ratio of correlations (HTMT). The HTMT is a measure of similarity between latent variables. In many practical situations, a threshold of 0.85 or 0.90 reliably distinguishes between those pairs of latent variables that are discriminant valid and those that are not (Henseler et al., 2015). Monte Carlo simulations provide evidence for HTMT's favorable classification performance (Voorhees et al., 2016). The results of HTMT calculation are shown in Table 3, which indicate that all construct's discriminant validity is confirmed (Henseler et al., 2015).

This paper appraises transformational leadership, psychological empowerment and international intrapreneurship as a particular conception. As presented in Table 4, the construct's dimensions reflect the higher-order constructs that can be supported by theory.

\subsection{Assessing structural models}

Evaluation of the model's predictive capabilities and the relationships in the structural model is undertaken via $R^{2}$ value, goodness-of-fit, Stone-Geisser's $Q^{2}$ and path coefficients

Table 3.

Discriminant validity test among research constructs with HeterotraitMonotrait ratio

\begin{tabular}{|c|c|c|c|c|c|c|c|c|c|c|}
\hline & 1 & 2 & 3 & 4 & 5 & 6 & 7 & 8 & 9 & VIF \\
\hline 1. Competence & & & & & & & & & & 1.30 \\
\hline 2. Impact & 0.108 & & & & & & & & & 1.21 \\
\hline 3. Idealized influence & 0.047 & 0.324 & & & & & & & & 1.21 \\
\hline $\begin{array}{l}\text { 4. Individualized } \\
\text { consideration }\end{array}$ & 0.071 & 0.358 & 0.331 & & & & & & & 1.03 \\
\hline 5. Inspirational motivation & 0.099 & 0.267 & 0.263 & 0.435 & & & & & & 1.21 \\
\hline 6. Intellectual stimulation & 0.080 & 0.223 & 0.118 & 0.138 & 0.185 & & & & & 1.25 \\
\hline 7. Meaning & 0.421 & 0.097 & 0.184 & 0.055 & 0.078 & 0.045 & & & & 1.47 \\
\hline 8. Self-determination & 0.520 & 0.135 & 0.045 & 0.091 & 0.068 & 0.042 & 0.365 & & & 1.07 \\
\hline $\begin{array}{l}\text { 9. Employee international } \\
\text { strategic renewal behavior }\end{array}$ & 0.089 & 0.467 & 0.414 & 0.595 & 0.608 & 0.291 & 0.121 & 0.031 & & 1.56 \\
\hline $\begin{array}{l}\text { 10. Employee international } \\
\text { new business venture } \\
\text { behavior }\end{array}$ & 0.075 & 0.437 & 0.465 & 0.594 & 0.691 & 0.230 & 0.067 & 0.089 & 0.870 & \\
\hline
\end{tabular}




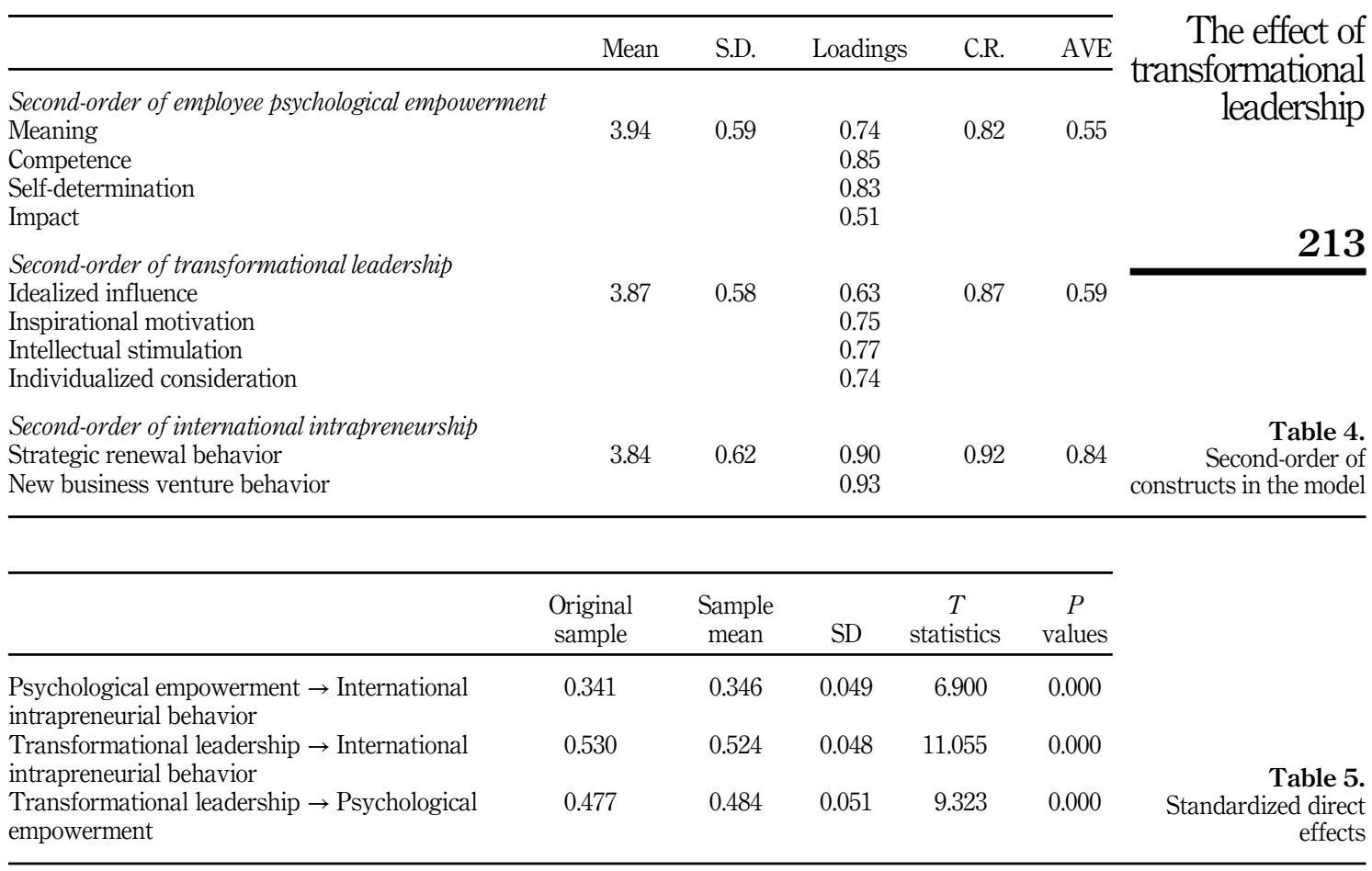

(Hair et al., 2019). The VIF values of the predictor constructs in the model are lower than 3.00, and thus collinearity is not an issue in the model (see Table 3) (Hair et al., 2017).

The $R^{2}$ value of the endogenous constructs is a measure of the model's explanatory power and in-sample predictive power (Hair et al.,2019). The $R^{2}$ value of the endogenous constructs in the model, namely psychological empowerment and international intrapreneurship, are 0.226 and 0.567 , respectively. The value of $F$ Square also reflects the significance of transformational leadership on psychological empowerment (0.295) and the effects of transformational leadership and psychological empowerment on intrapreneurship behavior ( $F$ Square $=0.208$ and 0.504, respectively). Standardized root-mean-square residual (SRMR) $=0.053$, thus providing the model fit (Joreskog and Sorbom, 1981). $Q^{2}$ values are found to be positive and higher than $0,0.25$, which depict small and medium predictive relevance of the PLS-path model: psychological empowerment $\left(Q^{2}=0.116\right)$ and international intrapreneurship $\left(Q^{2}=0.466\right)$.

4.2.1 Direct effects. Chin (1998) recommended that a bootstrapping procedure using 1,000 subsamples is performed to evaluate the statistical significance of each path coefficient. Table 5 shows hypothesized path coefficients, their bootstrap values and $T$ values.

In full support of Hypothesis 1 , transformational leadership is found to be positively and significantly related to employee international intrapreneurship $(\beta=0.530, t=11.055$, $p<0.001$ ). In full support of Hypothesis 2, transformational leadership is found to be positively and significantly related to employee psychological empowerment $(\beta=0.477$, $t=9.323, p<0.001$ ). Employee psychological empowerment is revealed to be directly and significantly effects on employee international intrapreneurship $(\beta=0.341, t=6.900$, $p<0.001)$. Therefore, Hypothesis 3 is fully supported by the data.

4.2.2 Indirect effects. Table 6 reveals the partial mediation of employee psychological empowerment in the relationship between transformational leadership and employee 
JABES 28,3

\section{4}

international intrapreneurship $(\beta=0.162, t=4.989, p<0.001)$. Therefore, Hypothesis 4 is fully supported by the data.

The estimated results of the reversed mediation model (dependent variable $\rightarrow$ mediators $\rightarrow$ independent variables) show the model fit as standardized root mean square residual $(\mathrm{SRMR})=0.077$. The results reveal that the hypothesized model is the best representation of the data SRMR $=0.053$, which indicates that the proposed model is preferred to the reversepath model in this study (Baron and Kenny, 1986). Table 7 shows the total effects of the final hypothesized model.

\section{Discussion and conclusions}

\subsection{Discussion}

The study sheds light on the advanced knowledge on the process that transformational leaders in family firms may foster human capital with the intrapreneurship process through building comprehensive relationships between family factors and nonfamily members (Huynh, 2021). International intrapreneurship is crucial in creating wealth for firms (Do and Luu, 2020; Hisrich, 2013; Skarmeas et al., 2016; Wolf and Redford, 2019; Yan et al., 2020). International intrapreneurship might reinvigorate firm performance with innovation and change adaption in the domestic and external environments (Badoiu et al., 2020; Covin and Slevin, 1991; Duradoni and Di Fabio, 2019; Rigtering and Weitzel, 2013). However, intrapreneurship studies in the international business and drivers for the long-term performance of family firms in emerging markets context have dropped behind those in Western settings (De Clercq and Zhou, 2014; Samiee et al., 2015; Urbano et al., 2013). During increased uncertainly in the export environment, employee skills, education and industry experience affect international performance (Javalgi and Todd, 2011). The important human capital dimensions for SMEs internationalization are managerial skills, international experience and the knowledge of the export environment (Dar and Mishra, 2019). The paper provides empirical evidence that family-owned firms can enhance intrapreneurship activities from transformational leadership and through the mediating role of employee psychological empowerment. Transformational leadership is a crucial factor in pursuing the competitive advantage of family through intrapreneurial behaviors. Family-owned firm

Table 6.

Total standardized indirect effects of transformational leadership on international intrapreneurship with mediating effects of psychological empowerment

\begin{tabular}{lcccccl}
\hline Paths & $\begin{array}{c}\text { Original } \\
\text { sample }\end{array}$ & $\begin{array}{c}\text { Sample } \\
\text { mean }\end{array}$ & SD & $\begin{array}{c}T \\
\text { statistics }\end{array}$ & $\begin{array}{c}P \\
\text { values }\end{array}$ & Mediation effect type \\
\hline $\begin{array}{l}\text { To employee international intrapreneurship via psychological empowerment } \\
\text { Transformational }\end{array}$ & 0.162 & 0.168 & 0.033 & 4.989 & 0.000 & $\begin{array}{l}\text { Complementary - } \\
\text { partial mediation }\end{array}$ \\
leadership & & & & & &
\end{tabular}

\begin{tabular}{lccccc}
\hline & $\begin{array}{c}\text { Original } \\
\text { sample }\end{array}$ & $\begin{array}{c}\text { Sample } \\
\text { mean }\end{array}$ & SD & $\begin{array}{c}T \\
\text { statistics }\end{array}$ & $\begin{array}{c}P \\
\text { values }\end{array}$ \\
\hline $\begin{array}{l}\text { Psychological empowerment } \rightarrow \text { International } \\
\text { intrapreneurial behavior }\end{array}$ & 0.341 & 0.346 & 0.049 & 6.900 & 0.000 \\
$\begin{array}{l}\text { Transformational leadership } \rightarrow \text { International } \\
\text { intrapreneurial behavior }\end{array}$ & 0.693 & 0.692 & 0.034 & 20.630 & 0.000 \\
$\begin{array}{l}\text { Transformational Leadership } \rightarrow \text { Psychological } \\
\text { empowerment }\end{array}$ & 0.477 & 0.484 & 0.051 & 9.323 & 0.000 \\
\hline
\end{tabular}

Table 7.

Total effects of the final hypothesized model 
leaders with ownership power create the most important foundation for the successful implementation of strategic direction and transformational leadership, thereby influencing intrapreneurial behaviors. The contribution of entrepreneurship theory to international business theories might be obtained from related developments in corporate entrepreneurship. Applying intrapreneurship theorizing to complement studies of internationalization seems a promising international strategy, particularly relevant when a firm venture abroad with the founding of new organizational units and the outcome of a change in firm strategy and thus reflect organizational renewal (Onetti et al., 2012).

Transformational leadership positively and significantly influence employee international intrapreneurship activities. Transformational leadership might stimulate employee creativity, innovation, adaptability and proactivity at work through an organization's innovative climate (Khalili, 2016; Moriano et al., 2014; Wang et al., 2017). Transformational leaders are visionaries, inspirational, courageous and adventurous, which are coherent with intrapreneur traits (Alam et al., 2020; Mahmoud et al., 2020; Marques et al., 2019; Woo, 2018). Transformational leadership might reinforce intrapreneurship in the direct and indirect channels. In the direct approach, leaders influence innovative employee behavior through their deliberate actions to stimulate idea generation and application and daily behavior (Gerards et al., 2020). Besides, transformational leadership may adopt mediating mechanisms to promote employee intrapreneurial behavior, namely entrepreneurial orientation, corporate social responsibility practices, organizational learning and innovation culture, job autonomy, employee psychological empowerment, organizational empowerment, organizational identification and organizational support (Amankwaa et al., 2019; Chang et al., 2017; Lei et al., 2020; Sattayaraksa and Boon-itt, 2016; Yariv and Galit, 2017). Transformational leadership's overall effect on employee intrapreneurial behavior is consistent in the existing literature (Afsar and Umrani, 2019; Amankwaa et al., 2019; Sanders and Shipton, 2012; Shafi et al., 2020; Tung, 2016). This paper investigates transformational leadership directly and significantly influences international intrapreneurship in different mechanisms. The organizational context might control these mixed results, that intrapreneurship is conducted (Rosing et al., 2011). Firm type plays a crucial role in promoting employee intrapreneurial behavior by providing a supportive innovation climate (Basco et al., 2020; Camelo-Ordaz et al., 2012; Kuratko and Audretsch, 2013; Lee and Kim, 2019; Urbano et al., 2013).

In family firms, transformational leaders may use intellectual stimulation and personal concern to delegate power to subordinates, and charismatic factors and ideological influences can nurture undesirable dependencies and leaders (Fries et al., 2020; Stanescu et al., 2020). Besides, empowerment has negative effects associated with patriotism, undermining the organization and creativity of employees. Employees who feel a clear role, have access to important organizational information, and work in a participatory environment feel more communicated (Anning-Dorson and Nyamekye, 2020). Transformational leadership is positively related to innovative behavior only when psychological empowerment is high (Grošelj et al., 2020). Empowerment plays an important role in building commitment, loyalty and involvement of subordinates in the organization (AlKahtani et al., 2021; Francis and Alagas, 2020). Transformational leadership through empowerment can significantly affect the success of subordinates and organizations (Ali et al., 2020; Bantha and Nayak, 2020; Bose et al., 2020; Lei et al., 2020; Mansoor and Ali, 2020).

5.1.1 Theoretical implications. The study sheds light on the advanced knowledge on the process that transformational leaders in family firms may foster human capital with the intrapreneurship process through building comprehensive relationships between family factors and nonfamily members. The paper develops extensive knowledge of the methods for generating intrapreneurship activities within organizations, which might contribute to originate the integrative theory on international corporate entrepreneurship and
The effect of transformational leadership 
JABES 28,3

\section{6}

resource-based view perspective of international business in the context of the family business in an emerging market.

5.1.2 Managerial implications. The paper implies that a family-owned firm needs to develop dynamic competitiveness based on promoting human capital through intrapreneurship activities. Empowering subordination is an important process that helps define transformational leadership, build commitment and inspire work for subordinates. The family firms need to reallocate their resources to the link between transformational leadership and nonfamily international intrapreneurship activities with the influencing mechanism of psychological empowerment regarding cost savings and operational efficiency and effectiveness.

5.1.3 Research limitations and guidance for future research. This study also contains many limitations. The first limitation is relevant to the sample bias with a self-evaluation questionnaire and cross-sectional data. It is highly concerned about the generalizability of the findings because of nonprobability sampling methods with convenience sampling techniques. This implies that future international entrepreneurship research could benefit from longitudinal research designs at the intersection of internationalization and entrepreneurship. The second limitation concerns the research model scope. This paper has partly contributed to international business theory through family SMEs' export trading results interpretation based on entrepreneurship theory. However, each stage of international business of family firms requires different resources. Therefore, it is necessary to incorporate theoretical perspectives from both domains in explaining each stage of internationalization of family firms.

\subsection{Conclusions}

The family firms from emerging and transition economies are increasingly exploring and exploiting international markets' opportunities. However, increasing uncertainty in the international business environment requires a family firm's need for a lean strategic approach, which ignores the linear process of internationalization. This study complements the existing theory by placing international corporate entrepreneurship theory within the framework of international business theory and in the context of family business. The study examines and reveals the direct influence of transformational leadership on nonfamily employee international intrapreneurship and through the mediating role of psychological empowerment in the context of family firms in an emerging economy context.

\section{References}

Afsar, B. and Umrani, W.A. (2019), "Transformational leadership and innovative work behaviour: the role of motivation to learn, task complexity and innovation climate", European Journal of Innovation Management, Vol. 23 No. 3, pp. 402-428, doi: 10.1108/EJIM-12-2018-0257.

Ahimbisibwe, G.M., Ntayi, J.M., Ngoma, M., Bakunda, G. and Kabagambe, L.B. (2020), "The internationalization of small to medium-sized enterprises: do all levels in international networking matter?", Journal of Small Business and Enterprise Development, Vol. 27 No. 5, pp. 817-837, doi: 10.1108/JSBED-09-2019-0313.

Alam, M.Z., Kousar, S., Shabbir, A. and Kaleem, M.A. (2020), "Personality traits and intrapreneurial behaviour", Asia Pacific Journal of Innovation and Entrepreneurship, Vol. 14 No. 1, pp. 31-46, doi: 10.1108/APJIE-09-2019-0068.

Alayo, M., Maseda, A., Iturralde, T. and Arzubiaga, U. (2019), "Internationalization and entrepreneurial orientation of family SMEs: the influence of the family character", International Business Review, Vol. 28 No. 1, pp. 48-59.

Ali, M., Zhang, L., Shah, S.J., Khan, S. and Shah, A.M. (2020), "Impact of humble leadership on project success: the mediating role of psychological empowerment and innovative work behavior", 
The Leadership and Organization Development Journal, Vol. 41 No. 3, pp. 349-367, doi: 10.1108/ LODJ-05-2019-0230.

AlKahtani, N., Iqbal, S., Sohail, M., Sheraz, F., Jahan, S., Anwar, B. and Haider, S. (2021), "Impact of employee empowerment on organizational commitment through job satisfaction in four and five stars hotel industry", Management Science Letters, Vol. 11 No. 3, pp. 813-822.

Amankwaa, A., Gyensare, M.A. and Susomrith, P. (2019), "Transformational leadership with innovative behaviour", The Leadership and Organization Development Journal, Vol. 40 No. 4, pp. 402-420, doi: 10.1108/LODJ-10-2018-0358.

Anning-Dorson, T. and Nyamekye, M.B. (2020), "Be flexible: turning innovativeness into competitive advantage in hospitality firms", International Journal of Contemporary Hospitality Management, Vol. 32 No. 2, pp. 605-624, doi: 10.1108/IJCHM-12-2018-1014.

Antoncic, B. and Hisrich, R.D. (2003), "Clarifying the intrapreneurship concept", Journal of Small Business and Enterprise Development, Vol. 10 No. 1, pp. 7-24, doi: 10.1108/14626000310461187.

Arnold, K.A. (2017), "Transformational leadership and employee psychological well-being: a review and directions for future research", Journal of Occupational Health Psychology, Vol. 22 No. 3, pp. 381-393, doi: 10.1037/ocp0000062.

Arregle, J.L., Duran, P., Hitt, M.A. and Van Essen, M. (2017), "Why is family firms' internationalization unique? A meta-analysis", Entrepreneurship: Theory and Practice, Vol. 41 No. 5, pp. 801-831, doi: 10.1111/etap.12246.

Arzubiaga, U., Iturralde, T., Maseda, A. and Kotlar, J. (2018), "Entrepreneurial orientation and firm performance in family SMEs: the moderating effects of family, women, and strategic involvement in the board of directors", The International Entrepreneurship and Management Journal, Vol. 14 No. 1, pp. 217-244, doi: 10.1007/s11365-017-0473-4.

Avolio, B.J. and Bass, B.M. (2004), Multifactor Leadership Questionnaire, Mind Garden, Menlo Park, California.

Badoiu, G.A., Segarra-Ciprés, M. and Escrig-Tena, A.B. (2020), "Understanding employees' intrapreneurial behavior: a case study", Personnel Review, Vol. ahead-of-print No. ahead-ofprint, doi: 10.1108/PR-04-2019-0201.

Bai, W., Johanson, M., Oliveira, L. and Ratajczak-Mrozek, M. (2021), "The role of business and social networks in the effectual internationalization: insights from emerging market SMEs", Journal of Business Research, Vol. 129, pp. 96-109, doi: 10.1016/j.jbusres.2021.02.042.

Bantha, T. and Nayak, U. (2020), "The relation of workplace spirituality with employees' innovative work behaviour: the mediating role of psychological empowerment", Journal of Indian Business Research, Vol. ahead-of-print No. ahead-of-print, doi: 10.1108/JIBR-032020-0067.

Baron, R.M. and Kenny, D.A. (1986), "The moderator-mediator variable distinction in social psychological research: conceptual, strategic, and statistical considerations", Journal of Personality and Social Psychology, Vol. 51 No. 6, pp. 1173-1182.

Baruch, Y. and Holtom, B.C. (2008), "Survey response rate levels and trends in organizational research", Human Relations, Vol. 61 No. 8, pp. 1139-1160, doi: 10.1177/0018726708094863.

Basco, R., Hernández-Perlines, F. and Rodríguez-García, M. (2020), "The effect of entrepreneurial orientation on firm performance: a multigroup analysis comparing China, Mexico, and Spain”, Journal of Business Research, Vol. 113, pp. 409-421, doi: 10.1016/j.jbusres.2019.09.020.

Bass, B. and Avolio, B. (1997), Manual for the Multifactor Leadership Questionnaire, Mind Gardens, California.

Bauweraerts, J., Pongelli, C., Sciascia, S., Mazzola, P. and Minichilli, A. (2021), "Transforming entrepreneurial orientation into performance in family SMEs: are nonfamily CEOs better than family CEOs?”, Journal of Small Business Management, Latest Articles, pp. 1-32, doi: 10.1080/ 00472778.2020 .1866763 . 
JABES 28,3

\section{8}

Begum, S., Xia, E., Mehmood, K., Iftikhar, Y. and Li, Y. (2020), "The impact of CEOs' transformational leadership on sustainable organizational innovation in SMEs: a three-wave mediating role of organizational learning and psychological empowerment”, Sustainability, Vol. 12 No. 20, p. 8620.

Bester, J., Stander, M.W. and Van Zyl, L.E. (2015), "Leadership empowering behaviour, psychological empowerment, organisational citizenship behaviours and turnover intention in a manufacturing division”, SA Journal of Industrial Psychology, Vol. 41 No. 1, pp. 1-14.

Bird, M. and Wennberg, K. (2014), "Regional influences on the prevalence of family versus non-family start-ups", Journal of Business Venturing, Vol. 29 No. 3, pp. 421-436, doi: 10.1016/j.jbusvent. 2013.06.004.

Bose, S., Patnaik, B. and Mohanty, S. (2020), "The mediating role of psychological empowerment in the relationship between transformational leadership and organizational identification of employees", The Journal of Applied Behavioral Science, Online First. doi: 10.1177/0021886320920951.

Boukamcha, F. (2019), "The effect of transformational leadership on corporate entrepreneurship in Tunisian SMEs", The Leadership and Organization Development Journal, Vol. 40 No. 3, pp. 286-304, doi: 10.1108/LODJ-07-2018-0262.

Camelo-Ordaz, C., Fernández-Alles, M., Ruiz-Navarro, J. and Sousa-Ginel, E. (2012), “The intrapreneur and innovation in creative firms", International Small Business Journal, Vol. 30 No. 5, pp. 513-535, doi: 10.1177/0266242610385396.

Chang, Y.Y., Chang, C.Y. and Chen, C.W. (2017), "Transformational leadership and corporate entrepreneurship", The Leadership and Organization Development Journal, Vol. 38 No. 6, pp. 812-833, doi: 10.1108/LODJ-10-2015-0219.

Chin, W.W. (1998), "The partial least squares approach to structural equation modeling", in Marcoulides, G.A. (Ed.), Modern Methods for Business Research, Erlbaum, Mahwah, pp. 295-358.

Collins, J.C. and Porras, J.I. (1994), Built to Last: Successful Habits of Visionary Companies, Harper Business, New York.

Covin, J.G. and Slevin, D.P. (1991), "A conceptual model of entrepreneurship as firm behavior", Entrepreneurship: Theory and Practice, Vol. 16 No. 1, pp. 7-26, doi: 10.1177/ 104225879101600102.

Craig, J.B. and Moores, K. (2006), “A 10-year longitudinal investigation of strategy, systems, and environment on innovation in family firms", Family Business Review, Vol. 19 No. 1, pp. 1-10, doi: 10.1111/j.1741-6248.2006.00056.x.

Dabić, M., Maley, J., Dana, L.P., Novak, I., Pellegrini, M.M. and Caputo, A. (2020), "Pathways of SME internationalization: a bibliometric and systematic review”, Small Business Economics, Vol. 55 No. 3, pp. 705-725, doi: 10.1007/s11187-019-00181-6.

Dar, I.A. and Mishra, M. (2019), "Internationalisation of SMEs: development and validation of a multidimensional measurement scale", International Journal of Entrepreneurship and Small Business, Vol. 38 No. 4, pp. 507-520, doi: 10.1504/IJESB.2019.104140.

De Clercq, D. and Zhou, L. (2014), "Entrepreneurial strategic posture and performance in foreign markets: the critical role of international learning effort", Journal of International Marketing, Vol. 22 No. 2, pp. 47-67, doi: 10.1509/jim.13.0131.

De Massis, A., Kotlar, J., Frattini, F., Chrisman, J.J. and Nordqvist, M. (2016), "Family governance at work: organizing for new product development in family SMEs", Family Business Review, Vol. 29 No. 2, pp. 189-213, doi: 10.1177/0894486515622722.

Deman, R., Jorissen, A. and Laveren, E. (2018), "Family control and innovativeness in private firms: the mediating role of board task performance", Management Decision, Vol. 56 No. 2, pp. 295-310, doi: 10.1108/MD-09-2016-0665.

Do, T.T.P. and Luu, D.T. (2020), "Origins and consequences of intrapreneurship with behaviour-based approach among employees in the hospitality industry", International Journal of Contemporary Hospitality Management, Vol. 32 No. 12, pp. 3949-3969, doi: 10.1108/IJCHM-05-2020-0491. 
Dunning, J.H. (1980), "Toward an eclectic theory of international production: some empirical tests", Journal of International Business Studies, Vol. 11 No. 1, pp. 9-31, doi: 10.1057/palgrave.jibs. 8490593.

Duradoni, M. and Di Fabio, A. (2019), "Intrapreneurial self-capital and sustainable innovative behavior within organisations", Sustainability, Vol. 11 No. 2, pp. 322-332, doi: 10.3390/su11020322.

Farahani, A.A.F. and Falahati, M. (2007), "The investigation of relationship between the psychological empowerment factors and intrapreneurship in the experts of physical education's offices in universities", Research on Sport Science, Vol. 5 No. 15, pp. 67-79.

Farahnak, L.R., Ehrhart, M.G., Torres, E.M. and Aarons, G.A. (2020), "The influence of transformational leadership and leader attitudes on subordinate attitudes and implementation success", Journal of Leadership and Organisational Studies, Vol. 27 No. 1, pp. 98-111, doi: 10.1177/1548051818824529.

Farrukh, M., Lee, J.W.C. and Shahzad, I.A. (2019), "Intrapreneurial behavior in higher education institutes of Pakistan", Journal of Applied Research in Higher Education, Vol. 11 No. 2, pp. 273-294, doi: 10.1108/JARHE-05-2018-0084.

Fong, K.H. and Snape, E. (2015), "Empowering leadership, psychological empowerment and employee outcomes: testing a multi-level mediating model", British Journal of Management, Vol. 26 No. 1, pp. 126-138.

Francis, R.S. and Alagas, E.N. (2020), "Hotel employees' psychological empowerment influence on their organizational citizenship behavior towards their job performance", Organizational Behavior Challenges in the Tourism Industry, IGI Global, pp. 284-304.

Fries, A., Kammerlander, N. and Leitterstorf, M. (2020), "Leadership styles and leadership behaviors in family firms: a systematic literature review", Journal of Family Business Strategy, Vol. 12 No. 1, 100374, doi: 10.1016/j.jfbs.2020.100374.

Galbreath, J., Lucianetti, L., Thomas, B. and Tisch, D. (2020), "Entrepreneurial orientation and firm performance in Italian firms: the moderating role of competitive strategy", International Journal of Entrepreneurial Behavior and Research, Vol. 26 No. 4, pp. 629-646, doi: 10.1108/IJEBR-072019-0457.

Gerards, R., van Wetten, S. and van Sambeek, C. (2020), "New ways of working and intrapreneurial behaviour: the mediating role of transformational leadership and social interaction", Review of Managerial Science, pp. 1-36, doi: 10.1007/s11846-020-00412-1.

Glinyanova, M., Bouncken, R.B., Tiberius, V. and Ballester, A.C.C. (2021), "Five decades of corporate entrepreneurship research: measuring and mapping the field", The International Entrepreneurship and Management Journal, pp. 1-27, doi: 10.1007/s11365-020-00711-9.

Gomez-Mejia, L.R., Makri, M. and Kintana, M.L. (2010), "Diversification decisions in family-controlled firms", Journal of Management Studies, Vol. 47 No. 2, pp. 223-252, doi: 10.1111/j.1467-6486.2009. 00889.x.

Grošelj, M., Černe, M., Penger, S. and Grah, B. (2020), “Authentic and transformational leadership and innovative work behaviour: the moderating role of psychological empowerment", European Journal of Innovation Management, Vol. ahead-of-print No. ahead-of-print, doi: 10.1108/EJIM-102019-0294.

Hair, J.F., Hult, G.T.M., Ringle, C.M. and Sarstedt, M. (2017), A Primer on Partial Least Squares Structural Equation Modeling (PLS-SEM), Sage, Thousand Oaks, California.

Hair, J.F., Risher, J.J., Sarstedt, M. and Ringle, C.M. (2019), "When to use and how to report the results of PLS-SEM”, European Business Review, Vol. 31 No. 1, pp. 2-24, doi: 10.1108/EBR-11-2018-0203.

Hart, S.L. (1995), "A natural-resource-based view of the firm", Academy of Management Review, Vol. 20 No. 4, pp. 986-1014, doi: 10.5465/amr.1995.9512280033.

Hashemi, S.M.K. and Nadi, H.K. (2012), "Agricultural personnel's intrapreneurial behavior: effects of perceived organizational support, psychological empowerment and entrepreneurial self efficacy”, International Journal of Agricultural Science and Research, Vol. 2 No. 1, pp. 11-19.

The effect of transformational leadership 
JABES 28,3
Hashimoto, M. and Nassif, V.M.J. (2014), "Inhibition and encouragement of entrepreneurial behavior: antecedents analysis from managers' perspectives", BAR-Brazilian Administration Review, Vol. 11 No. 4, pp. 385-406, doi: 10.1590/1807-7692bar2014130008.

Henseler, J., Ringle, C.M. and Sarstedt, M. (2015), “A new criterion for assessing discriminant validity in variance-based structural equation modeling", Journal of the Academy of Marketing Science, Vol. 43 No. 1, pp. 115-135, doi: 10.1007/s11747-014-0403-8.

Hill, S.A. and Birkinshaw, J. (2014), "Ambidexterity and survival in corporate venture units", Journal of Management, Vol. 40 No. 7, pp. 1899-1931, doi: 10.1177/0149206312445925.

Hisrich, R.D. (2013), “International entrepreneurship: where do we go from here?”, International Review of Entrepreneurship, Vol. 11 No. 1, pp. 1-13.

Huynh, T.T.G. (2021), "The influence of transformational leadership dimensions on intrapreneurial behaviour through mediators", Management Science Letters, Vol. 11 No. 7, pp. 2099-2114, doi: 10.5267/j.msl.2021.2.017.

Javalgi, R.R.G. and Todd, P.R. (2011), "Entrepreneurial orientation, management commitment, and human capital: the internationalization of SMEs in India”, Journal of Business Research, Vol. 64 No. 9, pp. 1004-1010, doi: 10.1016/j.jbusres.2010.11.024.

Jha, S. (2014), "Transformational leadership and psychological empowerment", South Asian Journal of Global Business Research, Vol. 3 No. 1, pp. 18-35, doi: 10.1108/SAJGBR-04-2012-0036.

Johanson, J. and Vahlne, J.E. (1990), “The mechanism of internationalisation”, International Marketing Review, Vol. 7 No. 4, doi: 10.1108/02651339010137414.

Joreskog, K.G. (1971), "Simultaneous factor analysis in several populations", Psychometrika, Vol. 36 No. 4, pp. 409-426.

Joreskog, K.G. and Sorbom, D. (1981), LISRELV User's Guide, International Educational Services, Chicago.

Kansikas, J., Laakkonen, A., Sarpo, V. and Kontinen, T. (2012), "Entrepreneurial leadership and familiness as resources for strategic entrepreneurship", International Journal of Entrepreneurial Behavior and Research, Vol. 18 No. 2, pp. 141-158, doi: 10.1108/13552551211204193.

Kanter, R. (1985), "Supporting innovation and venture development in established companies”, Journal of Business Venturing, Vol. 1 No. 1, pp. 47-60, doi: 10.1016/0883-9026(85)90006-0.

Khalili, A. (2016), "Linking transformational leadership, creativity, innovation, and innovationsupportive climate", Management Decision, Vol. 54 No. 9, pp. 2277-2293, doi: 10.1108/MD-032016-0196.

Klofsten, M., Urbano, D. and Heaton, S. (2021), "Managing intrapreneurial capabilities: an overview", Technovation, Vol. 99, p. 102177.

Kraiczy, N.D., Hack, A. and Kellermanns, F.W. (2015), "What makes a family firm innovative? CEO risk-taking propensity and the organizational context of family firms", Journal of Product Innovation Management, Vol. 32 No. 3, pp. 334-348, doi: 10.1111/jpim.12203.

Kuratko, D.F. and Audretsch, D.B. (2013), "Clarifying the domains of corporate entrepreneurship”, The International Entrepreneurship and Management Journal, Vol. 9 No. 3, pp. 323-335, doi: 10.1007/ s11365-013-0257-4.

Lampe, J., Kraft, P.S. and Bausch, A. (2020), "Mapping the field of research on entrepreneurial organizations (1937-2016): a bibliometric analysis and research agenda", Entrepreneurship: Theory and Practice, Vol. 44 No. 4, pp. 784-816, doi: 10.1177/1042258719851217.

Lan, X.M. and Chong, W.Y. (2015), "The mediating role of psychological empowerment between transformational leadership and employee work attitudes", Procedia-Social and Behavioral Sciences, Vol. 172, pp. 184-191, doi: 10.1016/j.sbspro.2015.01.353.

Lee, H.W. and Kim, E. (2019), "Workforce diversity and firm performance: relational coordination as a mediator and structural empowerment and multisource feedback as moderators", Human Resource Management, Vol. 59 No. 1, pp. 5-23, doi: 10.1002/hrm.21970. 
Lei, H., Leaungkhamma, L. and Le, P.B. (2020), "How transformational leadership facilitates innovation capability: the mediating role of employees' psychological capital", The Leadership and Organization Development Journal, Vol. 41 No. 4, pp. 481-499, doi: 10.1108/LODJ-062019-0245.

Lord, R.G., Epitropaki, O., Foti, R.J. and Hansbrough, T.K. (2020), "Implicit leadership theories, implicit followership theories, and dynamic processing of leadership information", Annual Review of Organizational Psychology and Organizational Behavior, Vol. 7, pp. 49-74, doi: 10.1146/annurevorgpsych-012119-045434.

Luu, D.T. (2020), "The effect of internal corporate social responsibility practices on pharmaceutical firm's performance through employee intrapreneurial behaviour", Journal of Organizational Change Management, Vol. 33 No. 7, pp. 1375-1400, doi: 10.1108/JOCM-03-2020-0072.

Luu, D.T. and Phan, V.H. (2020), "The effects of transformational leadership and job satisfaction on commitment to organisational change: a three-component model extension approach", The South East Asian Journal of Management, Vol. 14 No. 1, pp. 106-123, doi: 10.21002/seam.v14i1. 11585, ESCI (ISI).

Mahmoud, M.A., Ahmad, S. and Poespowidjojo, D.A.L. (2019), "The role of psychological safety and psychological empowerment on intrapreneurial behavior towards successful individual performance: a conceptual framework", Sains Humanika, Vol. 10 No. 3, pp. 65-72.

Mahmoud, M.A., Ahmad, S. and Poespowidjojo, D.A.L. (2020), "Intrapreneurial behavior, big five personality and individual performance", Management Research Review, Vol. ahead-of-print No. ahead-of-print, doi: 10.1108/MRR-09-2019-0419.

Malik, M., Sarwar, S. and Orr, S. (2021), "Agile practices and performance: examining the role of psychological empowerment", International Journal of Project Management, Vol. 39 No. 1, pp. 10-20, doi: 10.1016/j.ijproman.2020.09.002.

Mansoor, S. and Ali, M. (2020), "Transformational leadership and employee outcomes: the mediating role of psychological empowerment", The Leadership and Organization Development Journal, Vol. 42 No. 1, pp. 130-143, doi: 10.1108/LODJ-05-2020-0189.

Marques, C.S., Marques, C.P., Ferreira, J.J. and Ferreira, F.A. (2019), "Effects of traits, self-motivation and managerial skills on nursing intrapreneurship", The International Entrepreneurship and Management Journal, Vol. 15 No. 3, pp. 733-748, doi: 10.1007/s11365-018-0520-9.

McDougall, P.P. and Oviatt, B.M. (2000), "International entrepreneurship: the intersection of two research paths", Academy of Management Journal, Vol. 43 No. 5, pp. 902-906, doi: 10.5465/ 1556418.

Memili, E., Welsh, D.H. and Luthans, F. (2013), "Going beyond research on goal setting: a proposed role for organizational psychological capital of family firms", Entrepreneurship: Theory and Practice, Vol. 37 No. 6, pp. 1289-1296, doi: 10.1111/etap.12066.

Moghaddas, S.Z., Tajafari, M. and Nowkarizi, M. (2020), "Organizational empowerment: a vital step toward intrapreneurship", Journal of Librarianship and Information Science, Vol. 52 No. 2, pp. 529-540, doi: 10.1177/0961000619841658.

Montreuil, V.L., Lauzier, M. and Gagnon, S. (2020), "A closer look at determinants of organizational capability to innovate (OCI)", European Journal of Innovation Management, Vol. ahead-of-print No. ahead-of-print, doi: 10.1108/EJIM-05-2019-0127.

Moriano, J.A., Molero, F., Topa, G. and Mangin, J.P.L. (2014), "The influence of transformational leadership and organisational identification on intrapreneurship", The International Entrepreneurship and Management Journal, Vol. 10 No. 1, pp. 103-119, doi: 10.1007/s11365011-0196-x.

Mostafiz, M.I., Sambasivan, M. and Goh, S.K. (2020), "The performance of export manufacturing firms: roles of international entrepreneurial capability and international opportunity recognition", International Journal of Emerging Markets, Vol. ahead-of-print No. ahead-of-print, doi: 10.1108/ IJOEM-09-2019-0732.

The effect of transformational leadership 
JABES 28,3

Mubarik, M.S., Devadason, E.S. and Govindaraju, C. (2020), "Human capital and export performance of small and medium enterprises in Pakistan", International Journal of Social Economics, Vol. 47 No. 5, pp. 643-662, doi: 10.1108/IJSE-03-2019-0198.

Naqshbandi, M.M. and Tabche, I. (2018), "The interplay of leadership, absorptive capacity, and organizational learning culture in open innovation: testing a moderated mediation model", Technological Forecasting and Social Change, Vol. 133, pp. 156-167, doi: 10.1016/j.techfore.2018. 03.017.

Onetti, A., Zucchella, A., Jones, M.V. and McDougall-Covin, P.P. (2012), "Internationalization, innovation and entrepreneurship: business models for new technology-based firms", Journal of Management and Governance, Vol. 16 No. 3, pp. 337-368, doi: 10.1007/s10997-010-9154-1.

Oviatt, B.M. and McDougall, P.P. (1994), "Toward a theory of international new ventures", Journal of International Business Studies, Vol. 25 No. 1, pp. 45-64, doi: 10.1057/palgrave.jibs.8490193.

Oviatt, B.M. and McDougall, P.P. (2005), "The internationalization of entrepreneurship”, Journal of International Business Studies, Vol. 36 No. 1, pp. 2-8, doi: 10.1057/palgrave.jibs.8400119.

Özarall, N. (2015), "Linking empowering leader to creativity: the moderating role of psychological (felt) empowerment”, Procedia-Social and Behavioral Sciences, Vol. 181, pp. 366-376.

Park, S.H., Kim, J.N. and Krishna, A. (2014), "Bottom-up building of an innovative organization: motivating employee intrapreneurship and scouting and their strategic value", Management Communication Quarterly, Vol. 28 No. 4, pp. 531-560, doi: 10.1177/0893318914541667.

Pearson, A.W. and Marler, L.E. (2010), "A leadership perspective of reciprocal stewardship in family firms”, Entrepreneurship: Theory and Practice, Vol. 34 No. 6, pp. 1117-1124, doi: 10.1111/j.15406520.2010.00416.x.

Pittino, D. and Visintin, F. (2009), "Innovation and strategic types of family SMEs: a test and extension of miles and snow's configurational model", Journal of Enterprising Culture, Vol. 17 No. 3, pp. 257-295, doi: 10.1142/S0218495809000382.

Podsakoff, P.M., MacKenzie, S.B., Lee, J.Y. and Podsakoff, N.P. (2003), "Common method biases in behavioral research: a critical review of the literature and recommended remedies", Journal of Applied Psychology, Vol. 88 No. 5, pp. 879-903, doi: 10.1037/0021-9010.88.5.879.

Pradhan, R.K., Panda, M. and Jena, L.K. (2017), "Transformational leadership and psychological empowerment”, Journal of Enterprise Information Management, Vol. 30 No. 1, pp. 82-95, doi: 10. 1108/JEIM-01-2016-0026.

Rao-Nicholson, R., Khan, Z., Akhtar, P. and Merchant, H. (2016), "The impact of leadership on organisational ambidexterity and employee psychological safety in the global acquisitions of emerging market multinationals", International Journal of Human Resource Management, Vol. 27 No. 20, pp. 2461-2487, doi: 10.1080/09585192.2016.1204557.

Ratten, V. (2020), "Coronavirus and international business: an entrepreneurial ecosystem perspective”, Thunderbird International Business Review, Vol. 62 No. 5, pp. 629-634, doi: 10. 1002/tie.22161.

Rau, S.B., Werner, A. and Schell, S. (2019), "Psychological ownership as a driving factor of innovation in older family firms", Journal of Family Business Strategy, Vol. 10 No. 4, 100246, doi: 10.1016/j. jfbs.2018.03.001.

Rigtering, J.P.C. and Weitzel, U. (2013), "Work context and employee behaviour as antecedents for intrapreneurship", The International Entrepreneurship and Management Journal, Vol. 9 No. 3, pp. 337-360, doi: 10.1007/s11365-013-0258-3.

Ringle, C.M., Wende, S. and Becker, J.-M. (2015), SmartPLS 3, SmartPLS GmbH, Boenningstedt, available at: http://www.smartpls.com.

Rosing, K., Frese, M. and Bausch, A. (2011), "Explaining the heterogeneity of the leadershipinnovation relationship: ambidextrous leadership", The Leadership Quarterly, Vol. 22 No. 5, pp. 956-974, doi: 10.1016/j.leaqua.2011.07.014. 
Samiee, S., Chabowski, B.R. and Hult, G.T.M. (2015), "International relationship marketing: intellectual foundations and avenues for further research”, Journal of International Marketing, Vol. 23 No. 4, pp. 1-21, doi: 10.1509/jim.15.0027.

Sanders, K. and Shipton, H. (2012), "The relationship between transformational leadership and innovative behaviour in a healthcare context: a team learning versus a cohesion perspective”, European Journal of International Management, Vol. 6 No. 1, pp. 83-100, doi: 10.1504/EJIM.2012. 044759.

Sattayaraksa, T. and Boon-itt, S. (2016), "CEO transformational leadership and the new product development process", The Leadership and Organization Development Journal, Vol. 37 No. 6, pp. 730-749, doi: 10.1108/LODJ-10-2014-0197.

Schwens, C., Zapkau, F.B., Bierwerth, M., Isidor, R., Knight, G. and Kabst, R. (2018), "International entrepreneurship: a meta-analysis on the internationalization and performance relationship", Entrepreneurship: Theory and Practice, Vol. 42 No. 5, pp. 734-768, doi: 10.1177/ 1042258718795346.

Sengar, R., Chaudhary, N.S., Pande, S. and Rangnekar, S. (2020), "Psychological empowerment and entrepreneurship: insights from Indian corporate", International Journal of Business and Globalisation, Vol. 25 No. 2, pp. 185-203, doi: 10.1504/IJBG.2020.107886.

Shafi, M., Lei, Z., Song, X. and Sarker, M.N.I. (2020), "The effects of transformational leadership on employee creativity: moderating role of intrinsic motivation”, Asia Pacific Management Review, Vol. 25 No. 3, pp. 166-176, doi: 10.1016/j.apmrv.2019.12.002.

Shao, Z., Feng, Y. and Hu, Q. (2017), "Impact of top management leadership styles on ERP assimilation and the role of organizational learning", Information and Management, Vol. 54 No. 7, pp. 902-919, doi: 10.1016/j.im.2017.01.005.

Skarmeas, D., Lisboa, A. and Saridakis, C. (2016), "Export performance as a function of market learning capabilities and intrapreneurship: SEM and FsQCA findings", Journal of Business Research, Vol. 69 No. 11, pp. 5342-5347, doi: 10.1016/j.jbusres.2016.04.135.

Soper, D.S. (2020), “A-priori sample size calculator for structural equation models [Software]", available at: http://www.danielsoper.com/statcalc.

Sorenson, R.L. (2000), "The contribution of leadership style and practices to family and business success”, Family Business Review, Vol. 13 No. 3, pp. 183-200, doi: 10.1111/j.1741-6248.2000. 00183.x.

Spreitzer, G.M. (1995), "Psychological empowerment in the workplace: dimensions, measurement, and validation”, Academy of Management Journal, Vol. 38 No. 5, pp. 1442-1465, doi: 10.5465/256865.

Stanescu, D.F., Zbuchea, A. and Pinzaru, F. (2020), “Transformational leadership and innovative work behaviour: the mediating role of psychological empowerment”, Kybernetes, Vol. ahead-of-print No. ahead-of-print, doi: 10.1108/K-07-2019-0491.

Tipu, S.A.A. (2018), "What have we learned? Themes from the literature on organizational culture in family firms”, European Business Review, Vol. 30 No. 6, pp. 660-675, doi: 10.1108/EBR-022017-0042.

Tung, F.-C. (2016), "Does transformational, ambidextrous, transactional leadership promote employee creativity? Mediating effects of empowerment and promotion focus", International Journal of Manpower, Vol. 37 No. 8, pp. 1250-1263, doi: 10.1108/IJM-09-2014-0177.

Urbano, D., Alvarez, C. and Turró, A. (2013), “Organisational resources and intrapreneurial activities: an international study”, Management Decision, Vol. 51 No. 4, pp. 854-870, doi: 10.1108/ 00251741311326617.

Usman, M., Ali, M., Ogbonnaya, C. and Babalola, M.T. (2021), "Fueling the intrapreneurial spirit: a closer look at how spiritual leadership motivates employee intrapreneurial behaviors", Tourism Management, Vol. 83, 104227, doi: 10.1016/j.tourman.2020.104227.

Vallejo, M.C. (2011), “A model to study the organizational culture of the family firm”, Small Business Economics, Vol. 36 No. 1, pp. 47-64, doi: 10.1007/s11187-009-9175-9.
The effect of transformational leadership 
JABES 28,3

\section{4}

Voorhees, C.M., Brady, M.K., Calantone, R. and Ramirez, E. (2016), "Discriminant validity testing in marketing: an analysis, causes for concern, and proposed remedies", Journal of the Academy of Marketing Science, Vol. 44 No. 1, pp. 119-134, doi: 10.1007/s11747-015-0455-4.

Wan, W., Liu, L. and Wang, X. (2020), "How user-driven innovation and employee intrapreneurship promote platform enterprise performance”, Management Decision, Vol. 58 No. 12, pp. 2705-2723, doi: 10.1108/MD-06-2019-0701.

Wang, C.J., Tsai, H.T. and Tsai, M.T. (2014), "Linking transformational leadership and employee creativity in the hospitality industry: the influences of creative role identity, creative selfefficacy, and job complexity", Tourism Management, Vol. 40, pp. 79-89, doi: 10.1016/j.tourman. 2013.05.008.

Wang, H.J., Demerouti, E. and Le Blanc, P. (2017), “Transformational leadership, adaptability, and job crafting: the moderating role of organizational identification", Journal of Vocational Behavior, Vol. 100, pp. 185-195, doi: 10.1016/j.jvb.2017.03.009.

Watts, L.L., Steele, L.M. and Den Hartog, D.N. (2020), "Uncertainty avoidance moderates the relationship between transformational leadership and innovation: a meta-analysis", Journal of International Business Studies, Vol. 51 No. 1, pp. 138-145, doi: 10.1057/s41267-019-00242-8.

Wernerfelt, B. (1995), “The resource-based view of the firm: ten years after", Strategic Management Journal, Vol. 16 No. 3, pp. 171-174, doi: 10.1002/smj.4250160303.

Wolf, C. and Redford, D.T. (2019), "Fostering entrepreneurship for innovation in African Banks' subsidiaries", Africa Journal of Management, Vol. 5 No. 3, pp. 254-273, doi: 10.1080/23322373. 2019.1649558.

Woo, H.R. (2018), "Personality traits and intrapreneurship: the mediating effect of career adaptability", Career Development International, Vol. 23 No. 2, pp. 145-162, doi: 10.1108/CDI-02-2017-0046.

Yan, J., Tsinopoulos, C. and Xiong, Y. (2020), "Unpacking the impact of innovation ambidexterity on export performance: microfoundations and infrastructure investment”, International Business Review, Vol. 30 No. 1, 101766, doi: 10.1016/j.ibusrev.2020.101766.

Yang, M., Bento, P. and Akbar, A. (2019), "Does CSR influence firm performance indicators? Evidence from Chinese pharmaceutical enterprises”, Sustainability, Vol. 11 No. 20, 5656, doi: 10.3390/ su11205656.

Yariv, I. and Galit, K. (2017), "Can incivility inhibit intrapreneurship?”, Journal of Entrepreneurship, Vol. 26 No. 1, pp. 27-50, doi: 10.1177/0971355716677386.

\section{Corresponding author}

Giang Thi Thuy Huynh can be contacted at: gianghtt@uel.edu.vn

For instructions on how to order reprints of this article, please visit our website:

www.emeraldgrouppublishing.com/licensing/reprints.htm

Or contact us for further details: permissions@emeraldinsight.com 